\title{
IMMOBILIZATION OF LEVANSUCRASE: STRATEGIES AND BIOTECHNOLOGICAL APPLICATIONS
}

\author{
GABRIELLY TERASSI BERSANETI, CRISTIANI BALDO AND \\ MARIA ANTONIA PEDRINE COLABONE CELLIGOI* \\ Department of Biochemistry and Biotechnology, Centre of Exact Science, Londrina State University, \\ Highway Celso Garcia Cid - Pr 445 Km 380 - University campus, Mailbox 10.011 - CEP 86.057-970 - Londrina - PR, Brazil.
}

\section{ABSTRACT}

Immobilization is an excellent tool for enzymatic stabilization, improving the biocatalytic processes, allowing the reuse of the enzyme and promoting an easier separation of the molecule of interest. Currently, new enzymatic bonding processes are arising on solid supports, based on classical immobilization methods. Amongst the supports used, chitosan is a polysaccharide that offers a unique set of characteristics, as biocompatibility, biodegradability, non-toxicity and antibacterial properties. Thus, many enzymes has being immobilized on this support, including levansucrase, that is able to synthesize levan and fructooligosaccharides, two important biomolecules which have beneficial health properties. These review present different methods of immobilization (physical adsorption, entrapment, crosslinking and covalent bonding) for fructosyltransferases, as well as different immobilization matrices that can be applied in biotechnological processes. However, studies are still needed in order to adopt efficient immobilization techniques, in which the biocatalyst remains more stable, in order to become the process attractive to the industrial sector.

Key words: Applications, enzymatic immobilization, levansucrase, supports.

\section{INTRODUCTION}

Enzymatic immobilization is one technique of great interest in biotechnology research that can contribute to scientific community and industrial sectors. The scientific researches involving processes with immobilized enzymes is really important, since there is a reduction in the production time and costs due to the reuse of biocatalysts [1].

The main advantages of using immobilized enzymes in relation to enzymes in their free form are: facility of separating the catalyst from the product of the reaction without contamination; reutilization of the enzyme; reduction of the reaction volume, once the immobilized enzyme is retained in the support; possibility to take advantage of the catalytic activity for a longer period of time, since the enzyme should not be denatured at the end of the process. In some cases, changing the catalytic properties of the enzyme to its soluble form may increase the stability at $\mathrm{pH}$ and temperature, and reduce the inhibition caused by substrate and product that are continuously removed from the bioreactor [2].

The enzymes can be immobilized by different protocols as entrapment (encapsulated), adsorbed on insoluble materials or bind to a matrix by covalent bonds ${ }^{3}$. The physical nature of the supports varies from geliform materials to solid surfaces. The supports also can be classified as organic and inorganic according to their chemical composition. They are subdivided into natural and synthetic polymers, may also be microporous or not porous, microencapsulated, and exhibits a high, moderate or low-cross-linking degree $[3,4,5]$.

Various enzymes are currently immobilized, including levansucrase that are a fructosyltransferase capable of synthesizing fructooligosaccharides (FOSs) and levan, from sucrose. Immobilized enzyme becomes even more attractive for industries, due its ability to resist to many cycles of reutilization. Therefore, is possible to affirm that enzymatic immobilization increases the productivity of biocatalysts and improves their characteristics, becoming more interesting in various applications [3].

In this review, we highlight the main factors involved in the development of immobilized biocatalysts, which include types of supports, conditions and binding methods for enzymes, with special focus on levansucrase. We also discussed the production of biomolecules by immobilized levansucrase in chitosan, which constitute a model to study the key parameters of immobilization process.

\section{Levansucrase.}

According to the classification found in the database carbohydrate active enzymes, the bacterial levansucrase (E.C. 2.4.1.10 Sucrose-2,6- $\beta$-D-Fructsose$2,6-\beta-D$ - fructosyltransferase) belongs to the 68 family of glycosidic hydrolases (GH). Levansucrase shows three activities: transfructosylation (using monosaccharides, disaccharides or oligosaccharides as acceptors), hydrolysis (using water as acceptor) and polymerization (using the growing fructans as acceptor), releasing fructose, glucose, and synthesizing fructooligosaccharides and levan. These molecules shows relevant applications in the food, pharmaceutical and cosmetic industries $[6,7,8,9]$
Fructooligosaccharides are oligomers of fructose, in which fructosyl units are bound in the $\beta-2,1$ position of sucrose with a terminal glucose molecule that distinguishes them other oligomers [10]. The main fructooligosaccharides include 1-kestose (GF2), nystose (GF3), and 1- $\beta$-fructofuranosyl nystose (GF4). The $6 \mathrm{~F}-\mathrm{FOSs}$ represent 6 -kestose with fructose units connected by a $\beta-(2 \rightarrow 6)$ linkage, and 6G-FOSs are classified as neoFOSs (neokestose and neonystose) and present the $\beta-(2 \rightarrow 6)$ linkage between the fructose and sucrose glycosyl units $[11,12$ the kinetic for the bioconversion of sucrose to fructooligosaccharides (FOS]. The intermediate 6,6-nystose is formed from 6-kestose and is used as a basis for levan formation [13], schematic shown in Figure 1. Levan is a fructan consisting of $D$-fructose residues linked by $\beta$-glycosidic linkages $(2 \rightarrow 6)$ and may have branching points in $\beta-(2 \rightarrow 1)[14]$.

Several microorganisms are producers of levansucrase, as Bacillus Amyloliquefaciens [15], Bacillus subtilis natto [16], Geobacillus stearothermophilus [17], Erwinia amylovora [18] and Zymomonas mobilis [13].

The catalytic activity of levansucrase from B. subtilis is strongly influenced by the active site amino acids in the position Asp86-Glu342-Asp247, as defined by X-ray crystallography levansucrase [19].

The catalytic triad Asp86 / GLu342 / Asp247 was also localized in the active site of levansucrase produced by the gram-negative bacteria Gluconacetobacter diazotrophicus and by gram-positive bacteria as Bacillus subtilis and B. terium [20]. Despite the high complexity, various kinetic models are developed to predict the progress of the fructooligosaccharides synthesis reaction from sucrose. These models are of great interest for the definition of strategies for optimization [11]

The effects of substrate concentration, temperature and $\mathrm{pH}$ on the fermentation process can directly affect the extracellular levansucrase production. Belghith et al [21] reported that the use of sucrose has excellent effect on growth and activity, so the production of the enzyme is significantly influenced by the carbon source. Another determining factor in enzymatic reactions and cell growth is the medium $\mathrm{pH}$. The levansucrase optimal $\mathrm{pH}$ values ranging between 5.0 and $6.5[22,23]$.

The variation of temperature on the levansucrase activity has also been extensively studied. According to studies by Belghith et al [21], levansucrase from Bacillus sp. remained active at $50{ }^{\circ} \mathrm{C}$, showing remarkable stability and retained $100 \%$ of its original activity for more than $1 \mathrm{~h}$, showing be a thermostable enzyme. Bersaneti et al [16] was also verify the thermal stability of the levansucrase from $B$. subtilis, and the results showed that the enzyme was stable in all tested temperatures $\left(30,50,70\right.$, and $90{ }^{\circ} \mathrm{C}$ for $\left.2 \mathrm{~h}\right)$ with no significative loss of enzymatic activity.

\section{Immobilization methods for levansucrase.}

2.1. Physical Adsorption, Entrapment and Covalent Bonding.

The levansucrase can be immobilized by different methods. The enzyme could be entrapment (encapsulated), adsorbed on insoluble materials as ion exchange resins or bound to an insoluble matrix by covalent bonds [24,25,26,27]. Immobilization techniques, covalent binding, physical adsorption, entrapment in the matrix and gel. 


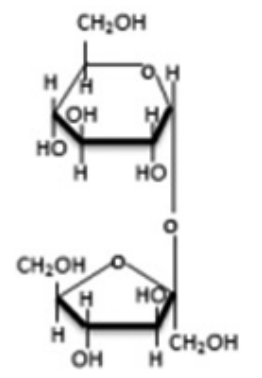

Sucrose
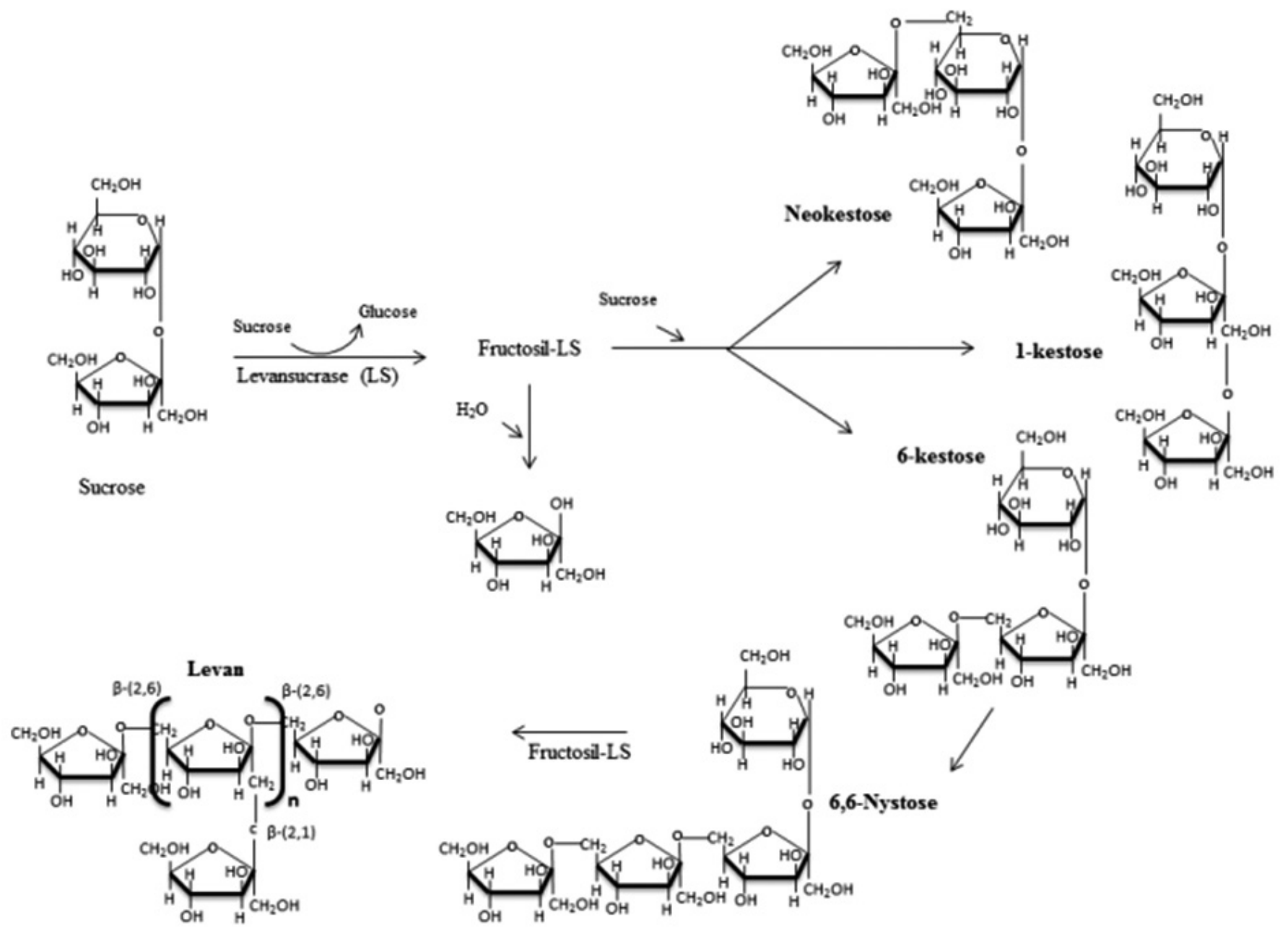

Fig 1: Formation of fructooligosaccharides and levan catalyzed by levansucrase (Fructosyl-LS refers to the fructosyl-enzyme intermediate).

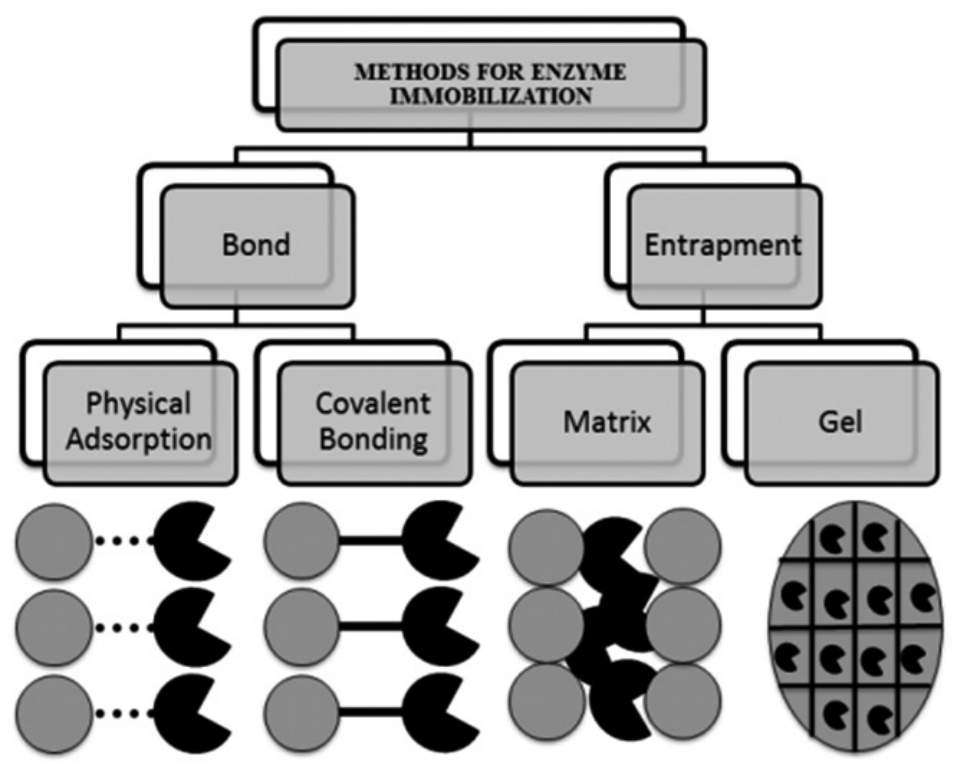

Fig 2: Immobilization techniques, covalent binding, physical adsorption, entrapment in the matrix and gel. 
The physical adsorption is the simplest method for the enzyme immobilization. The enzyme is stabilized in the support by weak interactions as Van der Waals forces, hydrophobic interactions, hydrogen bonds and ionic bonds. This method is highly attractive because when the enzymatic activity decreases, the support can be regenerated allowing a new immobilization [3, 28].

Another method used to immobilize enzymes is the entrapment, which consists of the physical retention of the enzyme in the internal cavities of a solid porous matrix, usually composed of crosslinked polymers such as polyacrylamide, gelatin, alginate, carrageenan and polyurethane resins [29]. This method allows modifying the encapsulating material and creating an optimal microenvironment for the enzyme, maintaining $\mathrm{pH}$ and polarity [3].

Other method is the covalent binding immobilization, which involves the binding of enzymes to water insoluble supports [30]. Covalent binding of enzymes to supports occurs in their side chain amino acids. The glutaraldehyde is used as the binding agent, acting as a bifunctional crosslinker, making bonds with amino groups in low acid and alkaline media [31]. It is soluble in aqueous solvents and can form stable inter- and intra-subunit covalent bonds [32]. The main advantage of this method is the higher resistance of the biocatalyst to the variation of $\mathrm{pH}$, temperature and influence of organic solvents.

Enzyme immobilized by covalent bonds can be employed in various types of reactors, such as continuous flow, fixed bed, stirred tank and fluidized bed, where the enzyme activity will remain constant, and do not detach from the support after being chemistry bonding [28, 33, 34].

Esawy et al [26] described the immobilization of levansucrase from Bacillus subtilis NRC33a using different methods including physical adsorption, covalent bonding, ionic bonding, and entrapment. The enzyme immobilized by covalent bonding on chitosan beads showed the highest yield of the immobilization $(81.51 \%)$, compared to other methods studied by the authors.

For enzymatic immobilization to occur efficiently, at least three fundamental factors must be considered: selection of support, methods of immobilization and conditions in which the enzyme will be exposed as $\mathrm{pH}$, temperature and agitation. It is important to maintain a microenvironment by the support matrix, which does not modify the stability and kinetic properties of the enzymes [3].

\section{Supports used in enzymatic immobilization.}

The selection of support can deeply influences the performance of the biocatalyst. Although there is no adequate universal support for all enzymes and certain characteristics of the carrier material should be considered, as the high affinity for the protein, biodegradability, material rigidity, viability of regeneration and non-toxicity [35]. Besides, the support must be highly porous, with large surface area, resistance to microbial attack and present the ability to increase enzymatic activity specificity [32,36].

Furthermore, materials used as supports should have low cost, large-scale facility of operation, high retention capacity and mechanical resistance for long operational life [37].

Various studies with immobilized levansucrase have been reported in the literature, with different supports as presented in Table 1.

Table 1: Different supports used in immobilization of levansucrase of various microorganisms.

\begin{tabular}{|c|c|c|c|}
\hline Enzyme & Supports & Microorganism & Reference \\
\hline Levansucrase & Glyoxyl agarose-IDA & Bacillus amyloliquefaciens & Hill et al [38] \\
\hline Levansucrase & $\begin{array}{c}\text { Chitosan and Sepabeads } \\
\text { EC }\end{array}$ & $\begin{array}{c}\text { Bacillus licheniformis } \\
\text { RN-01 }\end{array}$ & Sangmanee et al [39] \\
\hline Levansucrase & $\begin{array}{l}\text { Vinyl sulfone-activated } \\
\text { silica }\end{array}$ & Zymomonas mobilis & Santos-Moriano et al [24] \\
\hline Levansucrase & Eupergit $\AA$ and agarose & $\begin{array}{c}\text { Bacillus amyloliquefaciens, } \\
\text { ATCC } 23350\end{array}$ & Hill and Mateo [40] \\
\hline Levansucrase (commercial) & Chitosan & Aspergillus aculeatus & Lorenzoni et al [41] \\
\hline Levansucrase & Chitosan & Bacillus licheniformis & Dahech et al [42] \\
\hline $\begin{array}{l}\text { Levansucrase and endo- } \\
\text { inulinase }\end{array}$ & Sepabeads ${ }^{\circledR}$ EC HA/S & $\begin{array}{c}\text { Bacillus amyloliquefaciens and } \\
\text { Aspergillus niger }\end{array}$ & Tian et al [43] \\
\hline Levansucrase & DEAE-cellulose & Bacillus subtilis NRC33a & Esawy et al [26] \\
\hline Levansucrase & $\begin{array}{l}\text { Titanium-activated } \\
\text { magnetite }\end{array}$ & Zymomonas mobilis & Jang et al [44] \\
\hline Levansucrase & Hydroxyapatite & Zymomonas mobilis & Jang et al [27] \\
\hline
\end{tabular}

Among the supports found on the market and reported in the literature, chitosan, a natural polysaccharide used in the immobilization of levansucrase, showed good operational results in different reactors and for thermal stability of enzyme [39,40,41].

Chitosan (poly- $\beta(1 \rightarrow 4)$-2-amino-2-deoxy-D-glucose) is a cationic polysaccharide consisting of a linear chain of $\beta-(1-4)$ linked $\mathrm{N}$-acetylglucosamine (neutral sugar) and glucosamine (cationic sugar) [45].
The amino groups of the support can be easily activated with glutaraldehyde cross-linking reagent, forming bonds with the amino terminal of proteins [31].

Chitosan is a promising matrix support for enzymatic immobilization systems, as it has high affinity with proteins, adequate functional groups that bind covalently, high resistance to chemical degradation, and are easy to prepare in various physical forms. In addition, it exhibits antimicrobial properties and resists to storage and mechanical stress $[45,46,47]$. 

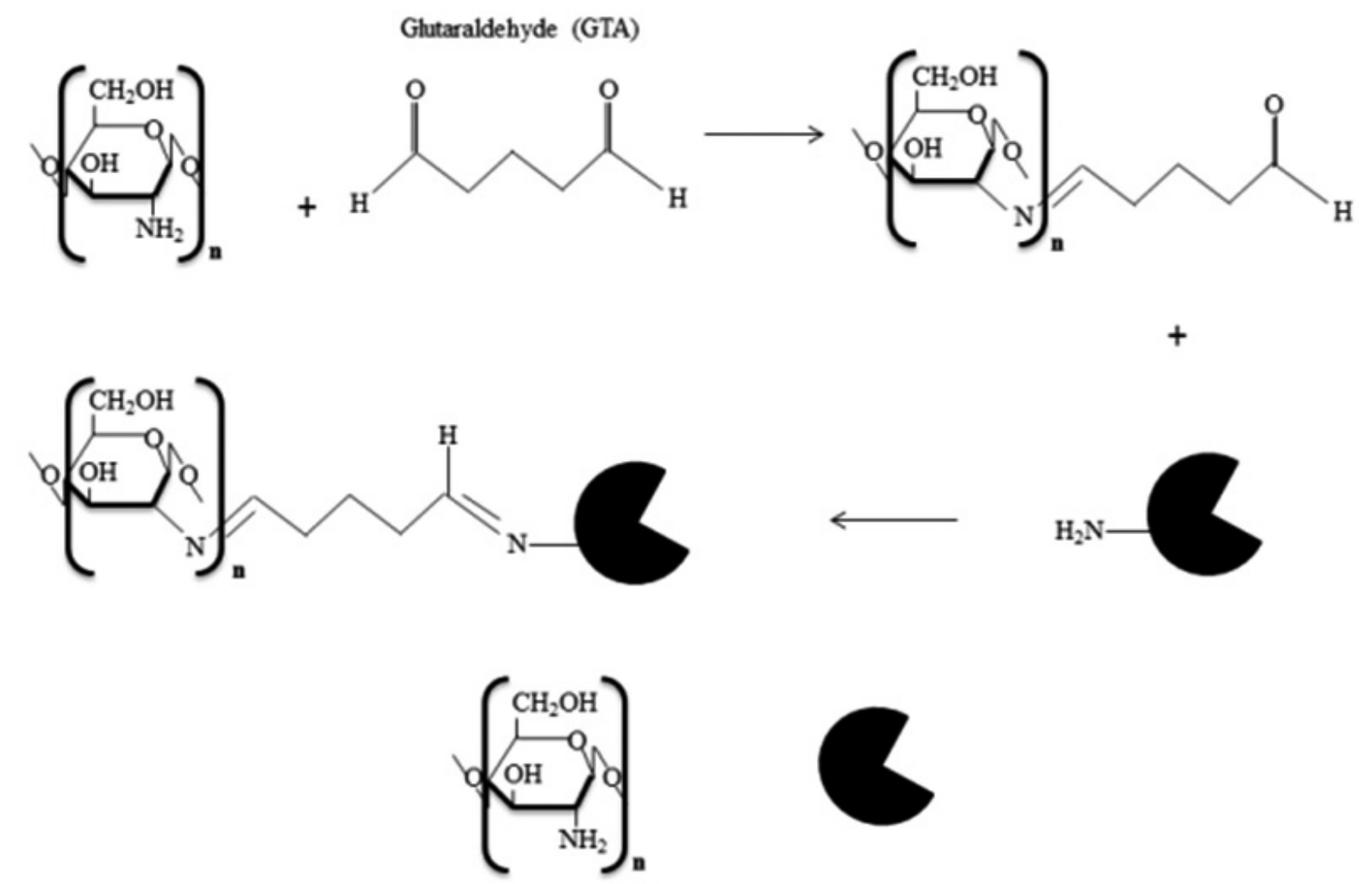

Chitosan

\section{Levansucrase}

Fig 3: Activation of chitosan support with amino group attachment using glutaraldehyde (GTA), and covalent attachment with amino groups of the enzyme levansucrase.

The first studies involving enzyme immobilization on chitosan supports were published in the 1970s. Muzzarelli et al [48] tested the adsorption of chymotrypsin on chitosan without using binding agent. Kasumi et al [49] immobilized glucose isomerase, urease, glucamylase, trypsin and glucose oxidase in chitosan using carbodiimide as the binding agent. Currently, research has been developed with the immobilization of enzymes in chitosan. Sangmanee et al [39] describes the immobilization of levansucrase on chitosan beads using glutaraldehyde as the binding agent for fructooligosaccharides synthesis.

The immobilization with chitosan beads is attracting great attention for industrial purposes because it stabilize the enzymes and present the possibility of reuse, which constitute key factors for the cost-benefit relation in industrial applications.

4. Production of biomolecules with immobilized levansucrase. Levansucrase can produce levan and fructooligosaccharides, depending on the microbial source of the enzyme and the conditions of reaction as sucrose concentration, $\mathrm{pH}$, temperature and reactors types $[6,16]$. Cellular production of levan and fructooligosaccharides is limited by the microorganism because the production of biomass, and the growth conditions may not be the same synthesis of both biomolecules [13, 40].

The production of biomolecules using immobilized enzymes was studied by Sangmanee et al [39]. The authors immobilized levansucrase from Bacillus licheniformis in chitosan beads, and reported that the maximum production of fructooligosaccharides was $7.35 \mathrm{~g} \mathrm{~L}^{-1}$ with $29.4 \%$ of yield, using $500 \mathrm{~g} \mathrm{~L}^{-1}$ of sucrose for $12 \mathrm{~h}$. The authors also reported that it is possible to reuse the immobilized enzyme for five consecutive cycles.

Ganaie et al [50] also immobilized a fructosyltransferase in chitosan, and evaluated the continuous fructooligosaccharides production for fifteen cycles with $600 \mathrm{~g} \mathrm{~L}^{-1}$ of sucrose solution. The results showed that the enzyme maintained its activity and production of fructooligosaccharides until the third cycle, presenting yield of $40.74 \%$.

The $\beta$-fructosyltransferase (commercial levansucrase) was immobilized by Lorenzoni et al [41] in chitosan beads and applied to the fructooligosaccharides synthesis. The authors used a fluidized and packed-bed reactor with $600 \mathrm{~g} \mathrm{~L}^{-1}$ of sucrose solution, reaching a maximum yield of $59 \%$ of fructooligosaccharides in packed-bed reactor.

The packed-bed reactor is one of the most used with immobilized biocatalysts. These are formed by an immobile column, where a substrate solution is pumped continuously. They stand out for the high catalytic capacity, easy increase of scale and operation. Besides, they cause minimal mechanical stress resulting in long-term stability and reduced process costs [51].

However, the use of immobilized enzymes in reactors still needs more studies, in order to find the best conditions to obtain a great productivity in large scale [52].

\section{Future perspectives and Conclusion}

Practical applications of immobilized enzymes in large-scale biotechnological processes are still limited. It is also known that immobilization of genetic engineering modified enzymes constitute one strategy for industrial process. However, there only may be advances in the construction of a biocatalyst with different tools, which enable genetic modifications in enzymes and chemical modifications in the supports.

In this sense, the utilization of recombinant enzymes including levansucrase, fructosyltransferase and $\beta$-fructofuranosidases combined with an efficient immobilization process, may be able to increase their stability, enabling the reuse of the biocatalyst through various cycles, and facilitating the production process and reduce costs, principally in large-scale applications.

Various immobilization protocols have been developed for the fructosyltransferases used in the food industry. When considering enzymatic reactions at any scale, from microreactors to industrial applications, the immobilization of the biocatalyst can be a crucial step for obtaining a more stable, simpler and economically viable bioprocess. Considering this, future studies are still necessary in order to improve the scalability of immobilization and the development of more efficient methods, concentrating primarily on enzymatic biocatalysts with an objective on industrial applications. Activation of chitosan support with amino group attachment using glutaraldehyde (GTA), and covalent attachment with amino groups of the enzyme levansucrase. 


\section{ACKNOWLEDGMENT}

The authors thank to Coordenação de Aperfeiçoamento de Pessoal de Nível Superior (CAPES/PNPD), Conselho Nacional de Desenvolvimento Científico e Tecnológico (CNPq), Fundação Araucária, Brazil for financial support.

\section{CONFLICT OF INTEREST}

The authors declare that there is no conflict of interest regarding the publication of this manuscript.

\section{REFERENCES}

1.- E. P. Cipolatti, A.Valério, R. O. Henriques, D. E. Moritz, J. L. Ninow, D. M. G. Freire, D. Oliveira. RSC Adv. 6, 104675-104692, (2016).

2.- L. Canilha, W. Carvalho, J. B. A. Silva. Biotecnologia, ciência e Desenvolvimento ano IX, 36, 48-57, (2006).

3.- N. R. Mohamad, N. H. C. Marzuki, N. A. Buang, F. Huyop, R. A. Wahab, Biotechnol. Biotechnol. Equipm. 29, 205-220, (2015).

4.- S. Gao, Y. Wang, X. Diao, G. Luo, Y. Dai. Bioresour. Technol. 101, 3830 3837, (2010).

5.- P. Zucca, R. Fernandez-Lafuente, E. Sanjust, Molecul. 21, 1-25, (2016).

6.- W. Li, S. Yu, T. Zhang, B. Jiang, W. Mu, Appl. Microbiol. Biotechnol. 99, 6959-6969, (2015).

7.- Y. Ben Ammar, T. Matsubara, K. Ito, M. Iizuka, N. Minamiura, Enzyme Microbial. Technol. 30, 875-882, (2002).

8.- K. Le Gorrec, C. Connes, A. Guibert, J.L. Uribelarrea, D. Combes. Enzyme Microbial Technol. 31, 44-52, (2002).

9.- B. L. Cantarel, P. M. Coutinho, C. Rancurel, T. Bernard, V. Lombard, B. Henrissat, Nucleic acids research. 37, 233-238, (2009).

10.- J. W. Yun. Enzyme Microbial Technol. 19, 107-117, (1996)

11.- F. Guio, L. D. Rugeles, S. E. Rojas, M. P. Palomino, M. C. Camargo, O. F. Sánchez. Appl. Biochem. Biotechnol. 167, 142-63, (2012).

12.- D. Linde, B. Rodríguez-Colinas, M. Estévez, A. Poveda, F. J. Plou, M. Fernández Lobato. Bioresour. Technol. 109, 123-130, (2012).

13.- P. Santos-Moriano, L. Fernandez-Arrojo, A. Poveda, J. Jimenez-Barbero, A. O. Ballesteros, F. J. Plou. J. Molecul. Catalysis B: Enzym. 119, 18-25, (2015).

14.- R. Srikanth, C. H. S. S. S. Reddy, G. Siddartha, M. J. Ramaiah, K. B. Uppuluri, Carbohydr. Polymers, 120, 102-114, (2015).

15.- F. T. Tian, L. Inthanavong, S. Karboune. 75, 1929-1938, (2011).

16.- G. T. Bersaneti, N. C. Pan, C. Baldo, M. A. P. C. Celligoi, Appl. Biochem. Biotechnol. 184, 838-851 (2017).

17.- L. Inthanavong, F. Tian, M. Khodadadi, S. Karboune, Biotechnol. Progr. 29, 1405-1415, (2013).

18.- Wuerges, J. Caputi, L. Cianci, M. Boivin, S. Meijers, R. Benini, S. J. Struct. Biol. 191, 290-298, (2015).

19.- J. Seibel, R. Moraru, S. Götze, K. Buchholz, S. Na'amnieh, A. Pawlowski, H. J. Hecht, Carbohydr. Resear. 341, 2335-2349, (2006).

20.- G. Meng, K. Fütterer. Nat. Struct. Biol. 10, 935-41, (2003).

21.- K. S. Belghith, I. Dahech, H. Belghith, H. Mejdoub, Int. J. Biol. Macromol. $50,451-8,(2012)$

22.- P. B. Silva, D. Borsato, M. A. P. C. Celligoi. Afr. J. Biotechnol. 13, 2734 2740, (2014).

23.- B. C. M. Gonçalves, J. Mantovan, M. L. L. Ribeiro, D. Borsato, M. A. P. C. Celligoi. J. Appl. Biol. Biotechnol. 1, 9-12, (2013).

24.- P. Santos-Moriano, L. Monsalve-Ledesma, M. Ortega-Munoz, L. Fernandez-Arrojo, A. O. Ballesteros, F. Santoyo-Gonzalezb, F. J. Plou. RSC Adv. 6, 64175-64181, (2016).

25.- L. Fernandez-Arrojo, B. Rodriguez-Colinas, P. Gutierrez-Alonso, M. Fernandez-Lobato, M. Alcalde, A. O. Ballesteros, F. J. Plou. Process Biochem. 48, 677-682, (2013).

26.- M. A. Esawy, D. A. R. Mahmoud, A. F. A. Fattah. Braz. J. Chem. Eng 25, 237-246, (2008).

27.- K. H. Jang, K. B. Song, J. S. Kim, C. H. Kim, B. H. Chung, S. K. Rhee, Bioprocess Eng. 23, 89-93, (2000).

28.- K. R. Jegannathan, S. Abang, D. Poncelet, E. S. Chan, P. Ravindra. Crit. Rev. Biotechnol. 28, 253-264, (2008).

29.- A. A. Mendes, P. C. Oliveira, H. F. Castro, R. L. C. Giordano. Quim. Nova. 34, 831-840, (2011).

30.- S. Karav, J. L. Cohen, D. Barile, J. M. L. N. de Moura Bell, Biotechnol. Progress. 33, 104-112, (2017).

31.- K. Okuda, I. Urabe, Y. Yamada, H. Okada. J. Ferment. Bioeng. 71, 100-
105, (1991).

32.- S. Datta, L. R. Christena, Y. R. S. Rajaram. 3 Biotech, 3, 1-9, 2013.

33.- R. Dalla-Vecchia, M. D. G. Nascimento, V. Soldi. Quim. Nova, 27, 623630, (2004).

34.- C. Mateo, J. M. Palomo, G. Fernandez-Lorente, J. M. Guisan, R. Fernandez-Lafuente. Enzyme Microb. Technol. 40, 1451-1463, (2007).

35.- M. L. Foresti, M. L. Ferreira, Enzyme Microb. Technol. 40, 769-777, (2007).

36.- C. Garcia-Galan, Á. Berenguer-Murcia, R. Fernandez-Lafuente, R. C. Rodrigues, Adv. Synth. Catal. 353, 2885-2904, (2011).

37.- J.G.C. Pradella, Reatores com células imobilizadas. Biotecnologia Industrial. W. Schmidell, U.A. Lima, E. Aquarone, W. Borzani, São Paulo: Ed. Edgard Blücher, 2001; cap.16; pp.355- 372.

38.- A. Hill, S. Karboune, C. Mateo, Process Biochem. 61, 63-72, (2017).

39.- S. Sangmanee, S. Nakapong, R. Pichyangkura, K. Kuttiyawong. J. Scienc. Technol. 38, 295-303, (2016).

40.- A. Hill, S. Karboune, C. Mateo. J. Chem. Technol. Biotechnol. 91, 24402448, (2015)

41.- A. S. G. Lorenzoni, L. F. Aydos, M. P. Klein, M. A. Z. Ayub, R. C. Rodrigues, P. F. Hertz. J. Mol. Catal. B: Enzym. 111, 51-55, (2015).

42.- I. Dahech, R. Bredai, K. Srih. Biochem. 8, 2013-2014, (2014).

43.- F. Tian, S. Karboune, A. Hill. Innov. Food Sci. Emerg. Technol. 22, 230 238, (2014).

44.- K.H. Jang, K. B. Song, B. S. C. H. Park, Kim, B. H. Chung, R. W. Choue, S.K. Rhee. Process Biochem. 37, 339-343, (2001).

45.- V. Zargar, M. Asghari, A. Dashti. Chem. Bio. Eng. Reviews. 2, 204-226, (2015).

46.- V. K. Thakur, M. K. Thakur. ACS Sustain. Chem. Eng. 2, 2637-2652, (2014)

47.- M. I. Wahba. Int. J. Biol. Macromol. 105, 894-904, (2017).

48.- R. Muzzarelli, G. Barontini, R. Rocchetti. Biotechnol. Bioeng. 18, 1445$54,(1976)$

49.- T. Kasumi, M. Tsuji, K. Hayashi, N. Tsumura, Agric. Biol. Chem. 41, 1865-1872, (1977).

50.- M. A. Ganaie, A. Lateef, U. S. Gupta. Appl. Biochem. Biotechnol. 172, 2143-59, (2014).

51.- S. Hama, S. Tamalampudi, A.Yoshida, N. Tamadani, N. Kuratani, H. Noda, H. Fukuda, A. Kondo. Biochem. Eng. J. 55, 66-71, (2011).

52.- E. Ricca, V. Calabrò, S. Curcio, A. Basso, L. Gardossi, G. Iorio, Int. J. Mol. Sci. 11, 1180-9, (2010) 